\title{
PENGARUH PENGGUNAAN HAND PADDLE DAN FINS SWIMMING TERHADAP KECEPATAN RENANG GAYA BEBAS PADA ATLET RENANG CLUB TIRTA BIMA MAJALENGKA
}

\author{
Bayu Dwi Febrianto \\ Universitas Majalengka, Indonesia \\ bayudwifebrianto@gmail.com
}

\begin{abstract}
ABSTRAK. Permasalahan dalam penelitian ini adalah para atlet pemula di Club Tirta Bima Kabupaten Majalengka kecepatan renang gaya bebasnya masih kurang. Penyebab dari kurangnya kecepatan renang gaya bebas di Club Tirta Bima adalah teknik renang para atlet pemula masih kurang benar, serta kayuhan tangan kurang bertenaga. Pada teknik berenangnya, pada gerakan pergelangan kaki masih melakukan gerakan memukul air bukan melecut di dalam air. Untuk itu diperlukan alat bantu untuk memperbaiki teknik berenangnya sekaligus mengembangkan kondisi fisiknya. Penulis mempunyai gagasan yaitu penggunaan hand paddle dan fins swimming dalam latihan renangnya. Dalam penelitian ini penulis merumuskan masalah: Adakah pengaruh penggunaan hand paddel dan fins swimming terhadap kecepatan renang gaya bebas pada atlit renang Club Tirta Bima Majalengka. Dengan tujuan Ingin mengetahui pengaruh penggunaan hand paddel dan fins swimming terhadap kecepatan renang gaya bebas pada atlit renang Club Tirta Bima Majalengka. Metode penelitian yang digunakan dalam penelitian ini adalah metode eksperimen. Penulis mengambil populasi penelitian atlet pemula di Club Tirta Bima Kabupaten Majalengka, jumlah sampel sebanyak 10 orang yang diambil dengan teknik total sampling. Berdasarkan hasil perhitungan diperoleh data secara keseluruhan kecepatan renang gaya bebas rata-rata tes awal 2,06 menit dan tes akhir 1,20 terjadi peningkatan skor sebesar 0,86 dengan nilai t hitung 15.5726 . Oleh karena nilai t hitung lebih besar dari t tabel $(15.5726>2,2622)$ dari data tersebut bisa ditarik kesimpulan bahwa hipotesis terdapat pengaruh yang signifikan penggunaan hand paddel dan fins swimming terhadap kecepatan renang gaya bebas pada atlit renang Club Tirta Bima Majalengka dapat diterima.
\end{abstract}

Kata Kunci: Renang Gaya Bebas, Hand Paddel, Fins Swimming

\section{Pendahuluan}

Dalam cabang olahraga renang ada beberapa gaya yang cukup popular, yaitu ; gaya bebas (the free style), gaya dada (breast stroke), gaya punggung (back stroke), gaya kupu-kupu (butterfly). Dalam hal ini, yang menjadi pusat pembahasan dalam penelitian ini adalah pada renang gaya bebas.

Kecepatan berenang yang optimal merupakan tujuan akhir dari proses latihan berenang. Berbagai bentuk latihan digunakan oleh pelatih dengan harapan kecepatan renang para atletnya bisa meningkat. Komponen-komponen yang bisa meningkatkan kecepatan berenang merupakan garapan dari para pelatih serta mengupayakan komponen-komponen tersebut bisa terlaksana dalam proses latihan. Seperti yang telah kita ketahui bersama dalam semua olahraga terukur termasuk renang, komponen yang bisa meningkatkan prestasi adalah komponen fisik (kondisi fisik) dan komponen teknik berenang. 
Latihan dikatakan efektif apabila dalam proses latihannya setiap elemen latihan berfungsi secara keseluruhan, atlet merasa senang, puas dengan hasil latihan, membawa kesan, materi dan cara latihan yang baik dari guru/pelatih. Tinjauan utama efektivitas latihan adalah outputnya, yaitu prestasi atlet. Efektivitas dapat dicapai apabila semua unsur dan komponen yang terdapat pada proses latihan berfungsi sesuai dengan tujuan dan sasaran yang ditetapkan.

Perkumpulan Renang Tirta Bima Majalengka merupakan salah satu dari beberapa Club renang yang berada di kota Majalengka. Berbagai prestasi pernah ditorehkan oleh para atlet yang bernaung di club ini. Akan tetapi dalam perkembangan olahraga renang yang terus meningkat diperlukan upaya mempertahankan dan meningkatkan prestasi renang para atletnya, salah satunya dengan menerapkan bentuk-bentuk latihan yang digali dari keilmuan atau teori latihan.

Berdasarkan hasil pra observasi penelitian di Club Renang Tirta Bima, para atlet pemulanya mengalami keterlambatan dalam peningkatan kecepatan renang gaya bebas. Penyebab dari kurangnya kecepatan renang gaya bebas di Club Tirta Bima adalah teknik renang para atlet pemula masih kurang benar, serta kayuhan tangan kurang bertenaga. Pada teknik berenangnya, pada gerakan pergelangan kaki masih melakukan gerakan memukul air bukan melecut di dalam air. Sehingga hanya menghasilkan cipratan air bukan mendorong air. Penyebab lain adalah kayuhan tangan yang lemah dikerenakan mereka belum memiliki power lengan yang memadai. Untuk itu diperlukan latihan yang tepat untuk memperbaiki teknik gerakan kaki dan menambah power lengannya

Kecepatan berenang gaya bebas juga berkaitan dengan latihan beban. Kurangnya tenaga pada fase kayuhan akan mengurangi kecepatan dalam luncuran. Kekurangan tenaga pada saat mengayuh (pada gerakan lengan) akan mengakibatkan berkurangnya kecepatan. Untuk itu meningkatkan kecepatan renang gaya bebas juga diperlukan latihan pembebanan ketika berenangnya.

Dari paparan di atas penulis mempunyai asumsi untuk menambah kecepatan waktu dibutuhkan latihan beban untuk melatih kualitas kekuatan otot tangan dan otot kaki. Latihan beban yaitu menggunakan sesuatu diluar badan untuk menambah dosis latihan. Untuk mendapatkan kecepatan dengan gaya bebas yang baik dibutuhkan gerakan kayuhan tangan dan kaki yang benar. Untuk melatih renang tersebut diperlukan sebuah alat yaitu hand paddle dan fins swimming (kaki katak). Renang dengan menggunakan alat tersebur merupakan salah satu teknik yang mempengaruhi dalam suatu cabang renang gaya bebas terutama bagi pemula. Menurut Dick (2008) mengungkapkan: “Alat peraga juga dapat mempertinggi pengajaran teknik gaya dan memaksimumkan pengaruh latihan" 


\section{Hand Paddel dan Fins Swimming dalam Latihan Renang Gaya Bebas}

Di dalam renang terdapat suatu prinsip ekonomi mengeluarkan tenaga sekecil mungkin, dan memperoleh daya laju yang seoptimal mungkin. Karena dalam gerakan renang melalui momentum di air sebagai akibat dari penyelaman dan dorongan. Tujuan berenang yang efiseien adalah menjaga momentum tetap konstan. Ketika perenang menggunakan kekuatan pada air, menyebabkan tubuh melaju dan secara simultan menghasilkan friksi resistensi pada air sehingga menyebabkan daya laju melambat. Momentum lebih besar, akan lebih mempercepat laju perenang, dan lebih mengefisienkan tenaga perenang sehingga tuntutan pengeluaran energi menjadi lebih rendah. Untuk mengimplementasikan prinsif tersebut, diperlukan penerapan pengetahuan khusus yaitu teori mekanika (hydrodinamika) renang.

Prinsip-prinsip mekanika renang ini perlu dipahami oleh guru dan pelatih selain untuk diterapkan bagi dirinya sendiri, juga sebagai bahan pengetahuan untuk mengajar atau melatih. Menurut Nugraha (2011) mengungkapkan: “Ada beberapa prinsip mekanika yang harus diperhatikan dan dipahami dalam renang adalah: daya apung (buoyancy), dorongan (propulsion), dan hambatan (resistance)". Prinsip-prinsip dalam renang ini dijadikan pertimbangan dalam menentukan metode latihan dan penggunaan alat bantu dalam berlatih renang.

Untuk menghasilkan daya dorong tubuh maju ke depan, dalam renang menurut Nugraha (2011) mengungkapkan: “...dihasilkan dari dua daya kekuatan/power force yaitu; yang dihasilkan dari kekuatan tarikan gerakan lengan, dan dari gerakan cambukan atau dorongan kaki”. Kedua daya kekuatan dilakukan bergerak secara sirnultan, seirama, dan sinkron, akan menghasilkan daya dorong tubuh bergerak maju secara optimal. Untuk menghasilkan daya dorong yang optimal diperlukan alat bantu latihan dalam berenang yaitu menggunakan hand paddle dan fins swimming

Hand paddel adalah piringan plastik yang dikenakan di atas telapak tangan perenang dan menempel di punggung tangan perenang dengan tali elastis, bentuknya berlubang dengan pola lubang. Penggunaan hand paddle ini lebih dianjurkan untuk perenang dengan stroke yang sudah baik/stabil (tidak berubah-ubah). Jadi penggunaan alat ini diberikan bukan pada siswa yang baru belajar renang akan tetapi atlet pemula yang memiliki kekuatan lengan yang masih rendah. Penggunaan hand paddle juga disesuaikan dengan usia, ukuran dan tujuan dari latihannya masing-masing. Untuk lebih jelasnya berikut gambar hand paddle

Atau dengan kata lain dengan menggunakan hand paddle dalam latihan renang kamu mendapatkan beberapa manfaat, tidak hanya mengembangkan kekuatan tubuh bagian atas, hand paddle juga dapat membantu mengembangkan teknik berenang, kamu menjadi sadar pada 
gerakan menarik lengan dan gerakan stroke dalam renang secara keseluruhan. Jadi ketika merasakan beban tahanan air ketika menarik lengan, kemudian kita bisa memperbaiki posisi tangan dan menekan secara maksimal air yang berada dibawah tubuh kita untuk menambah kecepatan dalam renang.

Penggunaan hand paddle selama latihan juga harus disesuaikan. Pada masa-masa awal program latihan gunakanlah hand paddle yang kecil, dan bertambah besar ukurannya seiring dengan perkembangan kekuatan atlet. Maksud cara seperti ini adalah untuk mengadaptasikan beban tahanan dengan kemampuan fisik (kekuatan) lengan para atlet pemula. Dengan bertambahnya hand paddle maka tahanan airnya semakin besar sehingga diperlukan kekuatan yang besar pula. Seteleh para atlet tersebut merasakan beban tahanannya dirasa ringan maka beban tersebut itu ditingkatkan secara progresif dengan cara menambah ukuran hand paddlenya.

Fins Swimming merupakan suatu alat bantu dalam latihan renang. Penggunaan alat ini diinspirasi dari ikan yang memiliki sirip pada bagian tubuh paling belakang, atau katak yang memiliki membran pada kaki belakangnya. Sirip dan membran pada kaki katak diduga menjadi penyebab dari kecepatan laju renang binatang tersebut.

Dalam perkembangan jaman yang semakin maju, Fins swimming digunakan pada program latihan renang khususnya pada renang gaya bebas dan gaya punggung. Fins swimming atau sirip kaki katak dikenakan pada kaki atau tungkai dan terbuat dari finlike karet atau plastik, tujuan menggunakan alat ini adalah untuk membantu gerakan kaki di dalam air. Fins swimming digunakan untuk bergerak di dalam air agar gerakan kaki tersebut efektif dan efisien pada laju renangnya.

Ketika atlet pemula menggunakan fins swimming, mereka bisa lebih cepat melaju di dalam air dan badan perenang terangkat ke atas permukaan air. Untuk perenang yang memiliki kayuhan kaki yang lemah, tungkai kaki biasanya terangkat ke atas sehingga laju renang tidak bisa cepat, maka dengan fins swimming ini kaki mereka akan selalu terjaga didalam air dan membantu tubuh pada posisi rata-rata air (streamlined position).

Penggunaan fins swimming juga berkaitan dengan perbaikan kebugaran jasmaninya (kondisi fisiknya). Kaki yang menggunakan fins swimming akan mengakibatkan kayuhan kaki menjadi berat. Dalam gerakan kayuhan ini akan menggunakan otot-otot tungkai yang besar. Secara tidak langsung hal ini akan melatih kekuatan dan daya tahan perenangnya. Dengan menggunakan otot-otot besar dalam tungkai, kamu akan mendapatkan manfaat yang bagus dalam sistem kardiovaskular membakar banyak kalori dan meningkatkan tingkat kebugaran jasmaninya. 
Kelenturan pergelangan kaki dalam renang gaya bebas juga sangat menentukan kecepatan laju renangnya. Dengan menggunakan fins swimming pergelangan kaki dipaksa bergerak dalam ruang gerak yang lebih luas. Peningkatan kelenturan pergelangan kaki akan mempercepat laju kedepan melewati air. Ini sangat penting bagi perenang dalam rangka meningkatkan kecepatan renangnya.

Manfaat lain dari fins swimming dalam latihan renang juga berkaitan dengan transfer dalam pembelajaran gerak. Transfer dalam pembelajaran gerak menurut Sugianto (2008) mengungkapkan: “... sebagai pengaruh latihan keterampilan sebelumnya terhadap belajar suatu keterampilan baru". Ketika para atlet tidak menggunakan fins swimming dalam berenang akan tetapi para atlet tersebut akan tetap melakukan dan merasakan gerakan yang sama ketika memakai fins swimming. Dari paparan yang telah disampaikan di atas, serta pendapat-pendapat para ahli penulis bisa mengambil asumsi bahwa latihan menggunakan hand paddle dan fins swimming akan memberikan pengaruh yang positif terhadap kecepatan renang gaya bebas pada atlet renang Club Tirta Bima Majalengka

\section{Metode Penelitian}

Jenis penelitian yang akan digunakan dalam penelitian ini adalah penelitian eksperimen. Dalam penelitian ini penulis mencoba meneliti pengaruh latihan renang dengan menggunakan hand paddle dan pins swimming sebagai perlakuan (treatment) terhadap kecepatan renang gaya bebas di Club Tirta Bima Kabupaten Majalengka. Peneliti akan memunculkan faktor atau mengujicobakan variabel penggunaan hand paddle dan pins swimming sebagai upaya untuk meningkatkan variabel kecepatan renang gaya bebas.

Rancangan penelitian yang penulis gunakan adalah rancangan atau design penelitian eksperimen dalam bentuk one group pre test - post test design

Penulis memilih dan mengggunakan rancangan atau desain ini dikarenakan penulis ingin mengetahui perubahan atau peningkatan kecepatan renang akibat perlakuan atau treatment penggunaan latihan hand paddle dan pins swimming. Perubahan atau peningkatan kecepatan renang gaya bebas bisa dilakukan dengan cara membandingkan antara tes awal dan tes akhir. Perbedaan antara tes awal dan tes akhir bisa dianggap sebagai efek dari perlakuan.

Untuk lebih jelasnya berikut rancangan atau desain penelitian eksperimen dalam bentuk one group pre test - post test design yang akan penulis gunakan dalam penelitian.

Gambar. 3.1

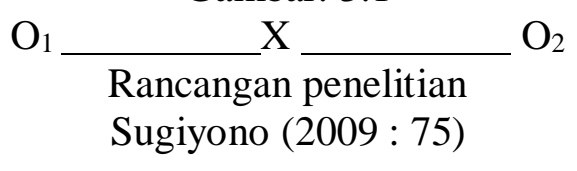


Keterangan:

$\mathrm{O}_{1} \quad$ : Pre test atau tes awal kecepatan renang gaya bebas

$\mathrm{X} \quad$ : Perlakuan latihan dengan hand paddle dan pins swimming

$\mathrm{O}_{2} \quad$ : Post test atau tes akhir kecepatan renang gaya bebas

Populasi yang digunakan dalam penelitian ini adalah seluruh atlet non pemula usia 10-14 tahun di Club Tirta Bima Kabupaten Majalengka sebanyak 10 orang.

Penulis mengambil sampel dengan teknik total sampling, atau keseluruhan populasi dijadikan anggota sampel. Berarti dalam penelitian ini penulis mengambil seluruh atlet nono pemula usia 10-14 tahun di Club Tirta Bima Kabupaten Majalaengka sebanyak 10 orang.

Instrumen dalam penelitian ini yaitu tes renang gaya bebas yang dicerminkan oleh waktu tempuh, maka instrumen dalam penelitian ini penulis menggunakan dengan bantuan alat yaitu stop watch untuk mengukur waktu tempuhnya, serta kolam renang dengan jarak 50 meter.

Pengumpulan data dilakukan dengan metode observasi sistematis dengan bantuan instrumen atau alat ukur yang telah dijelaskan di atas. Pengumpulan data dilakukan dua kali yaitu pada tes awal dan tes akhir. Sebelum melaksanakan pengetesan penulis terlebih dahulu mempersiapkan prosedur, sarana dan prasarana serta personil yang dibutuhkan dalam tes.

Setelah seluruh data hasil pengetesan terkumpul, maka langkah berikutnya adalah melakukan analisis data. Untuk mengetahui ada tidaknya pengaruh perlakuan latihan menggunakan hand paddle dan pins swimming yang diberikan yang diujicobakan pada atlet pemula di Club Tirta Bima, dalam menganalisis data peneliti mengggunakan rumus-rumus sebagai berikut :

1. Mencari deskripsi data yang terkumpul, yaitu rata-rata, simpangan baku dan varian.

2. Uji normalitas data

3. Pengujian Homogenitas

4. Pengujian Hipotesis

\section{Pembahasan}

Keberadaan peralatan dan alat bantu dalam usaha meningkatkan performa di dunia renang diharapkan menjadi solusi dalam rangka memperbaiki dan meningkatkan prestasi para atlet. Sehingga berbagai program latihan untuk atlet pemula hingga dewasa bisa dilaksanakan tanpa mengalami hambatan.

Dari hasil penelitian pada atlet pemula yang mengikuti latihan renang di Club Tirta Bima Kabupaten Majalengka penulis menemukan hal-hal yang penting tentang upaya meningkatkan kecepatan renang melalui latihan dengan hand paddle dan fins swimming 
Gaya bebas adalah berenang dengan posisi dada menghadap ke permukaan air. Kedua tangan dan kedua kaki secara bergantian digerakkan dengan gerakan mengayuh, dicambukkan naik turun ke atas dan ke bawah, ternyata dalam latihannya memerlukan beberapa alat bantu untuk memperbaiki teknik dari renangnya,

Kayuhan tangan dan cambukan kaki yang efektif dan efisien memerlukan kekuatan dan kelenturan dari setiap sendi yang digerakannya. Penggunaan hand paddle dan fins swimming dalam latihan renang gaya bebas ternyata terbukti memperbaiki teknik renang dan kekuatan kayuhan dan cambukan. By using hand paddles in training you can have some great benefits, not just the development in your upper body strength. Hand paddles can help you to develop your swimming technique as you become much more aware of your arm pull and general swimming stroke.

Pendapat sejalan yang mendukung bahwa fins swimming atau flipper sangat efektif dan efisien dalam meningkatkan kecepatan renang.

1. Using flippers will improve a swimmers body position and their technique.

2. Using flippers will increase your fitness and cardiovascular conditioning

3. Using flippers will help you to increase your ankle flexibility

4. Using flippers will give you the feeling of swimming fast through the water

Hand paddle dan fins swimming dalam latihan renang juga berkaitan dengan transfer dalam pembelajaran gerak. Setelah latihan dengan hand paddle dan fins swimming para atlet tersebut tetap melakukan dan merasakan gerakan yang sama ketika memakai hand paddle dan fins swimming. Pola gerak yang telah terbentuk selama latihan menggunakan peralatan ini akan tersimpan dalam memori, dan akan melakukan pola gerak yang sama meskipun peralatan itu tidak digunakan.

\section{Simpulan}

Setelah melakukan penelitian di Club Renang Tirta Bima Kabupaten Mjalengka, penulis mendapatkan gambaran tentang pengaruh penggunaan hand paddle dan fins swimming dalam melatih renang. Berdasarkan hasil analisis data dan pembahasan yang telah diungkapkan, penulis menyimpulkan penelitian sebagai berikut: "Terdapat pengaruh yang signifikan penggunaan hand paddel dan fins swimming terhadap kecepatan renang gaya bebas pada atlit renang Club Tirta Bima Majalengka”.

\section{Daftar Pustaka}

Harsono, (2007) Teori dan Metodologi Pelatihan. Suplemen Untuk Buku Coaching dan Aspek-aspek Psikologis dalam Coaching. Bandung. Sekolah Pascasarjana UPI

Harsono, (1988) Coaching dan Aspek-aspek Psikologis dalam Coaching. Jakarta. CV. Tambak Kesuma 
Imanudin, I. (2008). Modul Ilmu Kepelatihan Olahraga. Bandung : Universtas Pendidikan Indonesia Maksum, A. (2012) Metode Penelitian Olahraga, Semarang : UNESA Pres,

Mulyana, B. (2008) Aktivitas Aquatik. Bandung : Fakultas Pendidikan Olahraga Kesehatan. UPI

Nugraha, E., dkk. (2011) Didaktik Metodik Pengajaran Renang Bandung : Prodi PGSD Jurusan Pendidikan Olahraga UPI

Poerwadarminta, W. J. S. (1984). Kamus Umum Bahasa Indonesia Edisi ketiga. Jakarta: Pusat Pembinaan dan Pengembangan Bahasa

Rob, O \& Tyler, J. B. (2008) Dasar-Dasar Renang Bandung : Penerbitan Angkasa

Satriya, dkk. (2007). Modul Metodologi Kepelatihan. Bandung : Universtas Pendidikan Indonesia FPOK

Sugianto. (2008). Perkembangan dan Belajar Motorik. Jakarta :Universitas Terbuka Departemen Pendidikan Nasional

Sugiyono. (2009). Metode Penelitian Kuantitatif Kualitatif dan $R \& D$. Bandung : Alfa Beta.

Sukmadinata, N. S. (2010) Metode Penelitian Pendidikan. Bandung : PT Remaja Rosdakarya. 